\title{
Flowering spectrum diversity of Vicia sepium
}

\author{
Nijolè Maršalkienė \\ Laboratory of Agrobiotechnology, \\ Lithuanian University of Agriculture, \\ Studentu St. 10, LT-53067 Kaunas \\ Akademija, Lithuania
}

\begin{abstract}
The bush vetch (Vicia sepium) takes one of the first places among leguminous grasses by the amount of proteins. The previous studies show that the bush vetch is one of the most perspective leguminous fodder grasses in Lithuania. The seeds of $13 \mathrm{~V}$. sepium cenopopulations from different places of the country were sown in spring in mixture with Phleum pretense and Festuca pratensis and investigated in an experimental station (central Lithuania, medium loam, pH-7) in 2004-2007. The aim of the work was to investigate the diversity of flowering spectrum and the environmental impact on the time of flowering of $V$. sepium. Oneand two-time flowering cenopopulations were found, and early and late flowering forms of the bush vetch were distinguished by the experimental season. Cenopopulations from southwestern and northern regions flowered twice more frequently than cenopopulations from the southern region. Cenopopulations originating from the eastern region were characterized by early and one-time flowering. The greatest influence on the flowering term and duration was exerted by the amount of precipitation.
\end{abstract}

Key words: Vicia sepium, cenopopulation, flowering, diversity, spectrum

\section{INTRODUCTION}

Vicia sepium is a bush vetch widely distributed in Europe and North Asia, introduced from the Old World to North America. V. sepium, same as $V$. sativa, is a pan-temperate species, which greatly extends its distribution area (Maxted, 1995). $V$. sepium is regarded as a primitive member of subgenus Vicia, because of its perennial habit, a relatively long peduncle and numerous flowers per peduncle (Maxted, 1995). V. sepium is a perennial hemicriptophyte, common on roadsides,

\footnotetext{
* Corresponding author. E-mail: nijole.petraityte@delfi.lt
}

meadows, pastures, hedgerows (Grigas, 1997). The flowers are hermaphrodite (have both male and female organs) and are pollinated by bees; they are melliferous, possess extra floral nectarines, which can attract ants that act as plant defenders (Lenoir, Pihlgren, 2006).

According to the number of proteins $V$. sepium occupies one of the first places among leguminous grasses (Sliesaravičius, 2001; Medvediev, 1956). The plant vegetates early, it is resistant to winter kill, preferred by animals, remains in herbage for a long time, is suitable as a constituent part of perennial meadow composites (Medvedev, 1956; Larin, 1951). In the second part of the 19th century there 
were some attempts to sow $V$. sepium in Russia, and in the 20th century it was sown in various regions of the former Soviet Union's European part and Western Siberia, yet the species was not cultivated (Medvedev, 1956). The research carried out at the Institute of Botany in 1978-1980 revealed that $V$. sepium is one of the most perspective species of leguminous green fodder in Lithuania (Vitkus, 1998).

One of the main problems that aggravates the usage of $V$. sepium is seed growing. One of the essential objectives of plant breeders is to develop species of high reproductive potential. Different literary sources indicate various flowering periods of $V$. sepium - from May to November. Flowering is a quintessential adaptive feature in plants: its correct timing ensures, for example, that plants do not produce seeds when they have not found favorable conditions for dispersal or germination. Flowering of plants is an outcome of complicated physiological, biochemical, genetic and other processes. The transition from a plant vegetative growth phase to the generative one is regulated by the balance of both external (photoand-thermal induction, growth regulators) and internal (genes and phytohormones) factors (Galston, 2001; Novickienè et al., 2001; Scharma, Fletcher, 2002). Environmental con- ditions induce plant flowering; however, there always exist flowering initiation differences conditioned by the environment and determined by species or genotype (Duchovskis, 1996).

The aim of the work was to investigate the diversity of flowering spectrum of $V$. sepi$u m$ and the impact of meteorological conditions on the flowering term and duration.

\section{MATERIALS AND METHODS}

The experimental subject was 13 bush vetch (V. sepium) cenopopulations from different places of the country (Table 1). The seeds were sown in the first half of May together with Phleum pretense and Festuca pratensis and investigated in the LUA Experimental Station (central Lithuania, medium loam, soil - LVg-p-w-cc(sc)Calc(ar)i-Epihypogleyic Luvisol, pH-7, medium potassium, medium phosphorus, medium humus) in 2004. Seeds were scarified (using fine glass paper) before sowing (to encourage germination). Phenological observations of vegetation stages were performed. Flowering was considered to have begun when $10 \%$ of peduncles started to flower. The flowering was considered to be massive if $50 \%$ of peduncles flowered (Šurkus, Gaurilčikaitè, 2002).

Table 1. Location and characterization of $V$. sepium habitats

\begin{tabular}{c|ccccc}
\hline Region & & Habitat place & Composition of soil & Habitat type \\
\hline \multirow{3}{*}{ Eastern } & 36 & Anyǩ̌čiu distr. Milaikiškès & Sandy loam & Meadow \\
\cline { 2 - 5 } & 26 & Utenos distr. Kuktiškès & Sandy loam & Woodland meadow \\
\cline { 2 - 5 } & 28 & Trakų distr. Ūbiškès & Sandy loam & Pasture \\
\hline \multirow{2}{*}{ Southern } & 40 & Kaunas distr. IX fortas & Clay loam & Meadow \\
\cline { 2 - 5 } & 31 & Prienų distr. Čiudiškiai & Sandy loam & Woodland meadow \\
\hline \multirow{2}{*}{ Northern } & 37 & Mažeikių distr. Ukrinai & Clay loam & Meadow \\
\cline { 2 - 5 } & 30 & Pasvalio distr. Paiešmėniai & Clay loam & Road side \\
\hline \multirow{3}{*}{ South western } & 34 & Tauragès distr. Batakiai & Clay loam & Pasture \\
\cline { 2 - 5 } & 35 & Tauragės distr. Lauksargiai & Clay loam & Pasture \\
\cline { 2 - 5 } & 28 & Raseinių distr. Kryžkalnis & Sandy loam & Meadow \\
\hline \multirow{3}{*}{ Western } & 23 & Šilutės distr. Priekulė & Clay loam & Meadow \\
\cline { 2 - 5 } & 32 & Šilutės distr. Rukai & Clay loam & Pasture \\
\cline { 2 - 5 } & 33 & Klaipėdos distr. Klaipėda & Clay & Pasture \\
\hline
\end{tabular}




\section{Lithuanian climatic conditions}

Lithuanian climate is transitional between the oceanic climate of Western Europe and continental climate of Eurasia. The oceanic climate has the greatest impact on the western region that is nearest to the sea. The further we move from the sea to the east, the less is its impact and, therefore, gradual shift to the continental climate can be observed. The cold time span (the average day and night temperature is $<0{ }^{\circ} \mathrm{C}$ ) is 90 to 105 days in the western region and up to 135 days in the northeast. The warm period (the average day and night temperature is $>0{ }^{\circ} \mathrm{C}$ ) in the greatest part of Lithuania lasts $230-250$ and 260-270 days in the western region, especially near the sea. The vegetation period is rather long: from 202 days in the western part to 169 days in the east. The sum of the effective temperatures over the period when the average day and night temperature tops $10{ }^{\circ} \mathrm{C}$ increases going southeast: from $1950^{\circ}$ in the northwest up to $2300^{\circ}$ in the southeast (Šalčininkai and Varena districts) (Basalykas et al., 1965).

\section{Meteorological conditions}

To estimate the weather data, the sum of positive temperatures, amount of precipitation and hours of sun shining (Figure) were calculated for three stages: late spring - early summer season (April (3rd decade) - June), summer season (July-August), and autumn season (September-October).

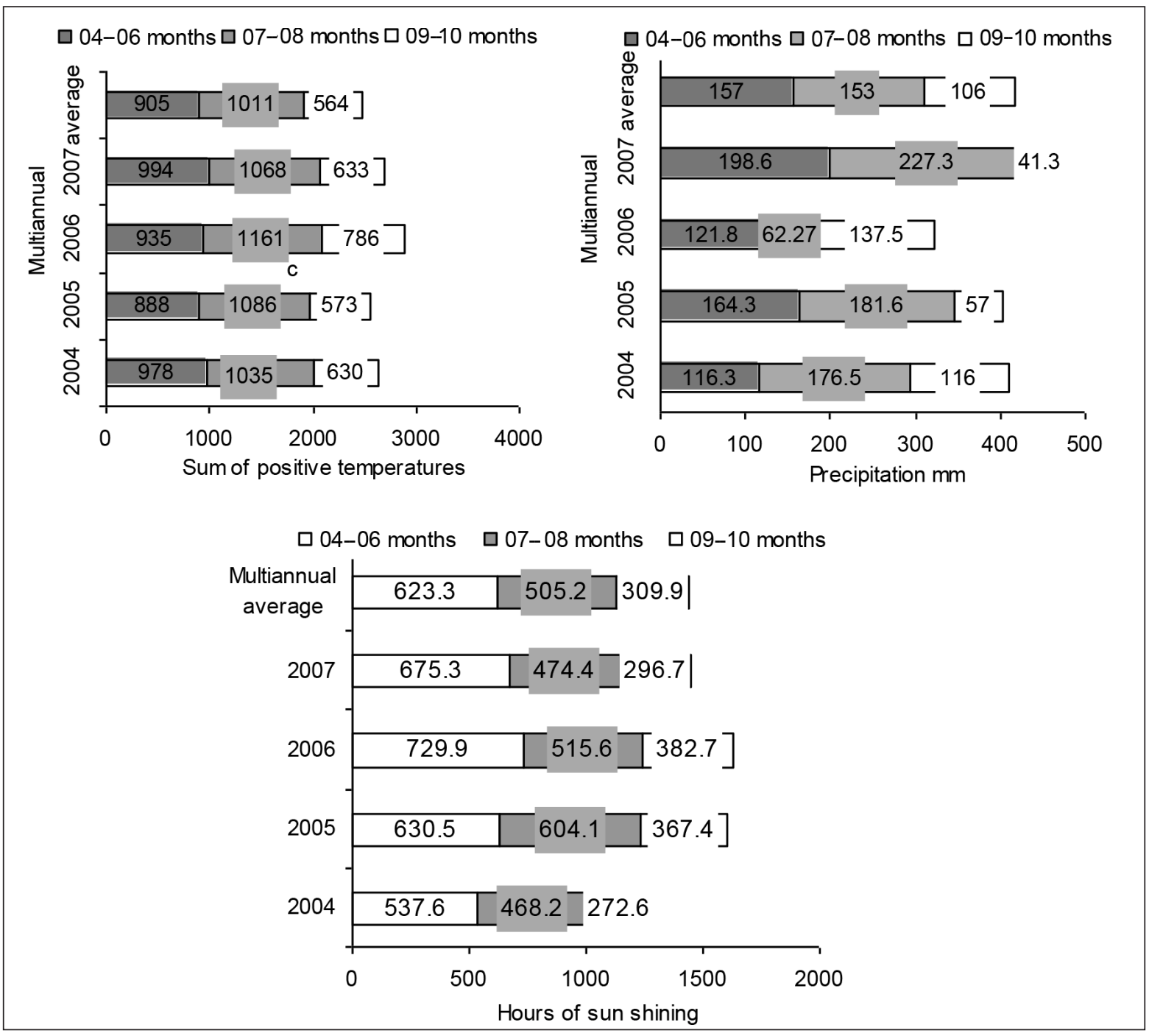

Figure. Meteorological conditions: A - sum of positive temperatures, B - amount of precipitation; C - hours of sun shining (LUA Experimental Station 2004-2007) 
Meteorological conditions over the research years varied considerably during the $V$. sepium vegetative experiment, that is, late spring - early summer seasons (April (3rd decade) - June) were ordinarily wet in 2004 and 2006 and wet in 2005 (Figure). Extremely hot and dry summer seasons (July-August) were observed in 2006, and wet in 2005. Meteorological conditions during autumn seasons (September-October) were dry in 2007 and wet in 2005, 2004, and 2006. The greatest number of sunny hours was observed over the period of spring-summer in 2006 (4-6 months) and the summer of 2005 (7-8 months) while the least number was noted in the autumn of 2004 and 2007 (910 months). All in all, the most favorable year for plant vegetation was 2007 which was seen as warm and bringing sufficient moisture, meanwhile, 2006 was the least favorable, dry and hot.

\section{RESULTS AND DISCUSSION}

Only plants of cenopopulation No. 32 bloomed during the first year (2004, August-September) of growth.

All investigated cenopopulations flowered during the second growth year. The amount of precipitation at the beginning of the springsummer period had the essential effect on the terms of flowering beginning in 2005-2007. The earliest flowering of $V$. sepium cenopopulations was observed in 2007, massive flowering began on May 20 (Table 1) when the amount of precipitation at the beginning of the springsummer period was the highest compared to other research years (Fig. 1B). The same early massive flowering (on May 25) started in 2005, though the temperature at the beginning of the spring-summer period was considerably lower than in 2007 and lower than the multiannual average (Fig. 1A), yet the amount of precipitation was sufficient (Fig. 2B). In the warm but dry spring of 2006, however, V. sepium began flowering 20 days later compared to the rest of the years. Moisture in 2006 was the limiting factor. Due to the lack of moisture, physiological and biochemical processes in plant cells slowed down, growth of plant vegetative mass and differentiation of vegetative growth cones in the buds into the generative ones weakened.

The average flowering of different cenopopulations lasted 35 days, while in the dry summer of 2006 the flowering was longer - 40 days, on the average (Table 2). Regardless of the early cenopopulations, the duration of flowering among cenopopulations differed by 5 to 10 days. The origin of cenopopulations did not have evident influence on flowering duration. Over all years of research, however, the flowering of cenopopulations No. 27 (eastern) and No. 31 (southern) was consistently long (45-40 days). The flowering phenospectrum of cenopopulations of hedge vetch originated from western (No. 33; 32; 29) and southwestern (No. 34; 35; 28) regions varied within 35-38 days.

According to the research data, two early eastern $V$. sepium cenopopulations, No. 27 and 28, and one late western cenopopulation, No. 14, were distinguished. Differences in early flowering of cenopopulations over three years of observation were not distinct and did not differ considerably.

All investigated eastern (No. 36; 27; 28) and one southern (No. 40) cenopopulations over the research years flowered once during vegetation. Vetches of the rest of cenopopulations flowered for the second time 40-55 days after the first flowering during all or several years of research (Table 3 ). The flowering of cenopopulations No. 30 of the northern region and No. 33 of the western region was consistently long and abundant (53.3 and 46.7 days, on the average, respectively) during all years of research.

The ecologic-geographic conditions of cenopopulations' origin could determine the following differences of cenopopulation flowering. A shorter period of vegetation compared to the western region, higher summer temperature, poorer sandy loam soil, more frequent deficit of moisture - conditions less favorable to vegetation - could be the determining factors for early flowering of eastern and southern cenopopulations and their property to flower once. Soil richer in nutrients, mild and moister oceanic climate conditioned late and a longer period of flowering of western cenopopulation 
Table 2. Fenospectrum of first flowering of $V$. Sepium cenopopulations

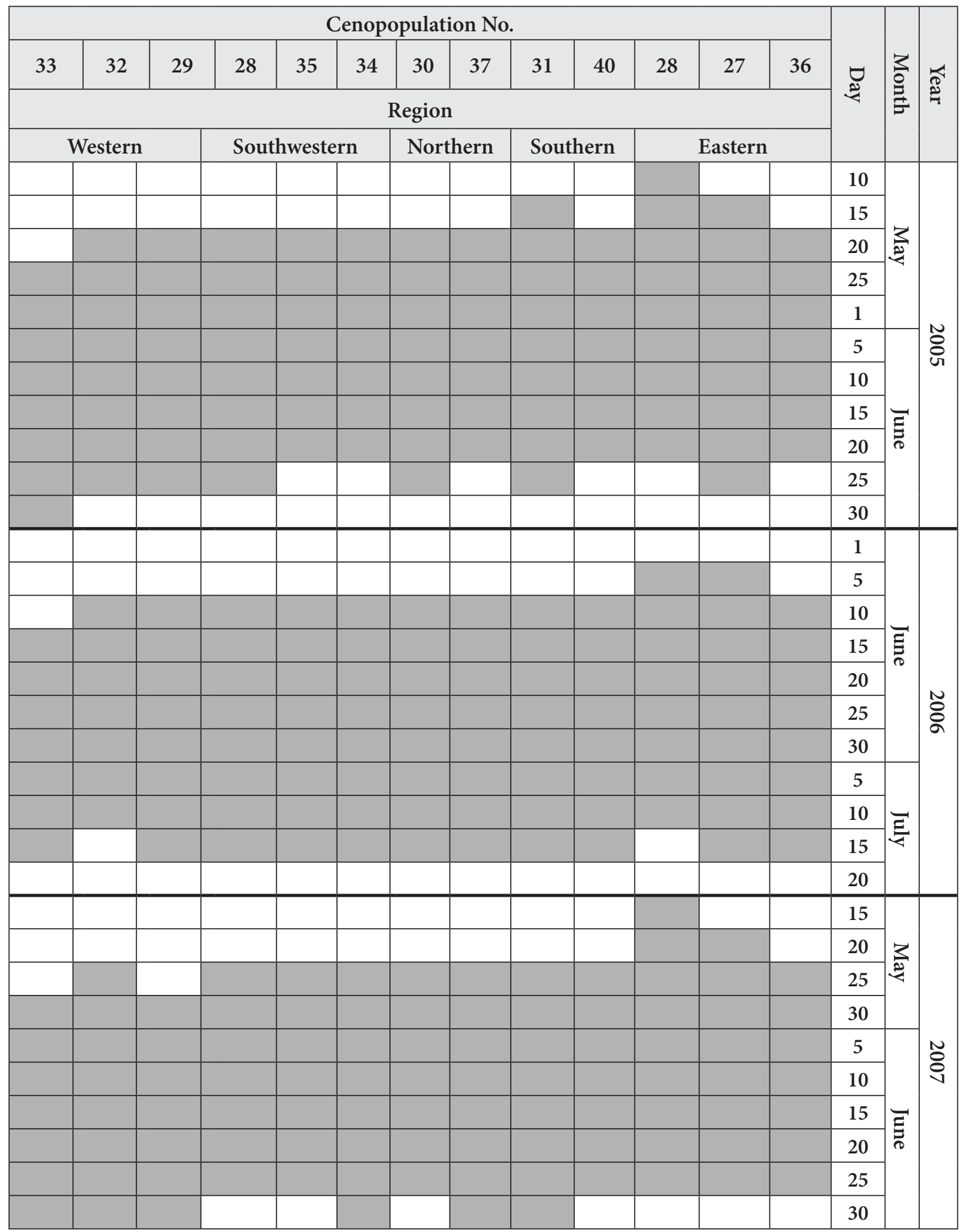

No. 33 compared to other cenopopulations. Similar factors of soil and climate could determine the property of other cenopopulations to flower for the second time.
It could be stated that cenopopulations flowering for the second time are heterogenic, consisting of different development level individuals (Batygin, 1986). In the second half of 
Table 3. Fenospectrum of second flowering of V. Sepium cenopopulations

\begin{tabular}{|c|c|c|c|c|c|c|c|c|c|c|c|c|c|c|c|}
\hline \multicolumn{13}{|c|}{ Cenopopulation No. } & \multirow{2}{*}{\multicolumn{3}{|c|}{ Collection No. }} \\
\hline 33 & 32 & 29 & 28 & 35 & 34 & 30 & 37 & 31 & 40 & 28 & 27 & 36 & & & \\
\hline \multicolumn{13}{|c|}{ Region } & \multirow{2}{*}{$\underset{\mathscr{H}}{\forall}$} & \multirow{2}{*}{$\frac{3}{3}$} & \multirow{2}{*}{ 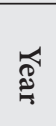 } \\
\hline & ester & & & hwes & & Nort & ern & Sout & & & Easter & & & & \\
\hline & & & & & & & & & & & & & 10 & \multirow{5}{*}{ August } & \multirow{13}{*}{ 葛 } \\
\hline & & & & & & & & & & & & & 15 & & \\
\hline & & & & & & & & & & & & & 20 & & \\
\hline & & & & & & & & & & & & & 25 & & \\
\hline & & & & & & & & & & & & & 30 & & \\
\hline & & & & & & & & & & & & & 5 & \multirow{6}{*}{ 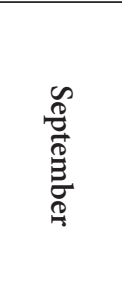 } & \\
\hline & & & & & & & & & & & & & 10 & & \\
\hline & & & & & & & & & & & & & 15 & & \\
\hline & & & & & & & & & & & & & 20 & & \\
\hline & & & & & & & & & & & & & 25 & & \\
\hline & & & & & & & & & & & & & 30 & & \\
\hline & & & & & & & & & & & & & 5 & \multirow{2}{*}{ October } & \\
\hline & & & & & & & & & & & & & 10 & & \\
\hline & & & & & & & & & & & & & 20 & \multirow{3}{*}{ August } & \multirow{13}{*}{ 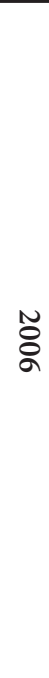 } \\
\hline & & & & & & & & & & & & & 25 & & \\
\hline & & & & & & & & & & & & & 30 & & \\
\hline & & & & & & & & & & & & & 5 & \multirow{6}{*}{ 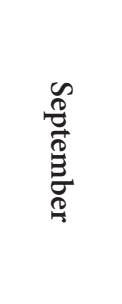 } & \\
\hline & & & & & & & & & & & & & 10 & & \\
\hline & & & & & & & & & & & & & 15 & & \\
\hline & & & & & & & & & & & & & 20 & & \\
\hline & & & & & & & & & & & & & 25 & & \\
\hline & & & & & & & & & & & & & 30 & & \\
\hline & & & & & & & & & & & & & 5 & \multirow{4}{*}{ October } & \\
\hline & & & & & & & & & & & & & 10 & & \\
\hline & & & & & & & & & & & & & 15 & & \\
\hline & & & & & & & & & & & & & 20 & & \\
\hline & & & & & & & & & & & & & 5 & \multirow{6}{*}{ 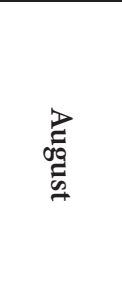 } & \multirow{11}{*}{ : } \\
\hline & & & & & & & & & & & & & 10 & & \\
\hline & & & & & & & & & & & & & 15 & & \\
\hline & & & & & & & & & & & & & 20 & & \\
\hline & & & & & & & & & & & & & 25 & & \\
\hline & & & & & & & & & & & & & 30 & & \\
\hline & & & & & & & & & & & & & 5 & \multirow{5}{*}{ 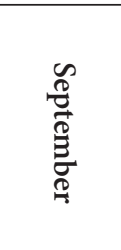 } & \\
\hline & & & & & & & & & & & & & 10 & & \\
\hline & & & & & & & & & & & & & 15 & & \\
\hline & & & & & & & & & & & & & 20 & & \\
\hline & & & & & & & & & & & & & 25 & & \\
\hline
\end{tabular}


summer, part of them form germs of flowers and start to blossom. More homogeneous cenopopulations, which have evolved in the eastern region, are characterized by a genetically determined feature to flower once. After relocation to a more fertile soil and another geographic region they retained the inherent qualities, that is, early, shorter and one-time flowering compared to other cenopopulations.

\section{CONCLUSIONS}

The amount of precipitation had the greatest influence on the flowering term and span of $V$. sepium. Cenopopulations originating from the eastern region were characterized by early and one-time flowering. The western cenopopulation was distinguished for late and abundant flowering twice during the vegetation. During the research years cenopopulations from southwestern and northern regions flowered twice more frequently than cenopopulations from the southern region. Differences of early flowering of cenopopulations and duration of flowering could be determined by the geographic conditions of cenopopulations' origin and edaphic conditions. After relocation to other eco-geographic conditions cenopopulations retained the inherent qualities of flowering fenospectrum.

The V. sepium flowering fenospectrum indicates not only inter-population-based but also intra-population-based diversity, its genetic potential.

Received 14 March 2016

Accepted 15 June 2016

\section{References}

1. Batygin N. Ontogenez vyšyh rastenyj. Moskva; 1986. Russian.
2. Basalykas A. Lietuvos TSR Fizinė geografija. Vilnius: Mintis, 1965.

3. Duchovskis P. Model of flowering ignition in perennial plants. Theoretical and practical problems in modern physiology of cultural plants. Collection of Scientific Articles. Babtai, LIH; 1996. p. 15-25.

4. Galston AW. Plant biology-retrocpect and prospect. Current Sci: Plant Mol Biol. 2001; 80(20): 143-52.

5. Grigas J. (ed.). Lithuania SSR flora-IV. Vilnius: Mintis; 1971.

6. Larin IV. Kopmovye pastenija senokosov i pastbich SSSR. 1951. Russian.

7. Lenoir L, Pihlgren A. Effects of grazing and ant/beetle interaction on seed production in the legume Vicia sepium in a seminatural grassland. Ecol Entomol. 2006; 31: 601-7.

8. Maxted N. An ecogeographical study of Vicia subgenus Vicia. Rome, Italy; 1995.

9. Medvedev PF. Kopmovye pastenija senokosov i pastbich SSSR. 1956. Russian.

10. Novickienė L, Raklevičienė D, Gavelienè V, Kazlauskienė D. Physiological analogues of auxin: effect on in vitro morphogenesis of rape. Proc Latv Acad Sci. 2001; 559(5/6): 201-6.

11. Sliesaravičius A, Petraityte N. Accumulation and research of the Lithuanian fodder legume venera Vicia L. and Lathyrus L. genetic recources. Biologija. 2001; 4: 61-5.

12. Šurkus I, Gaurilčikaitè I. Žemès ūkio augalu kenkejjai, ligos ir jų apskaita. Akademija, 2002.

13. Sharma VK, Fletcher JC. Maintenance of shoot and floral meristem cell proliferation and fare. Plant Physiol. 2002; 129: 31-9.

14. Vitkus A. Lietuvos TSR Mokslų Akademijos Darbai. Serija C, Biologijos Mokslai. 1988; 2: 44-49. 
Nijolė Maršalkienė

\section{VICIA SEPIUM ŽYDĖJIMO SPEKTRO IVAIROVE்}

\section{Santrauka}

Patvorinis vikis (Vicia sepium) pagal baltymų kiekị žoleje pirmauja tarp ankštinių žolių. Ankstesnių tyrimų duomenimis, patvorinis vikis yra viena perspektyviausių ankštinių pašarinių žolių Lietuvoje. Trylika V. sepium cenopopuliaciju sèklų iš skirtingų šalies vietų buvo pasèta kartu su paprastuoju motiejuku ir tikruoju eraičinu (Vidurio Lietuvoje, vid. sunkumo priemolyje $\mathrm{pH}-7$ ) ir 2004-2007 m. tirta bandymų stotyje. Darbo tikslas - ištirti ir ịvertinti žydejjimo spektro ìvairovę ir aplinkos poveiki $V$. sepium žydejimo laikui. Tyrimo metais buvo rastos ankstyvos ir vèlyvos, vieną ir du kartus žydinčios $V$. sepium cenopopuliacijos. Pietvakarinių ir šiaurinių rajonų cenopopuliacijos dažniausiai žydèjo du kartus, pietinių rajonų - vieną kartą. Rytinių rajonų cenopopuliacijos išsiskyre ankstyvu žydèjimu ir per vasarą žydejjo vieną kartą. Didžiausią poveikį žydèjimo pradžiai tyrimo metais turèjo kritulių kiekis pavasarị.

Raktažodžiai: Vicia sepium, cenopopuliacija, įvairové, žydejjimo spektras 